\title{
STUDI PENGEMBANGAN POTENSI OBJEK WISATA ANYAR MANGROVE (WAM) DI KELURAHAN GUNUNG ANYAR TAMBAK SURABAYA
}

\author{
Oleh : Sardi Umasugi ${ }^{\star}$ ) dan Suning ${ }^{* *}$ )
}

\begin{abstract}
Abstrak :
Kelurahan Gunung Anyar Tambak merupakan salah satu Kelurahan di Kecamatan Gunung Anyar Kota Surabaya yang terdapat objek wisata yang di beri nama Wisata Anyar Mangrove (WAM). Metode penelitian yang digunakan dalam studi pengembangan potensi objek wisata anyar mangrove (WAM) adalah metode penelitian deskriptif kualitatif dan metode analisis hirarki proses (AHP), dengan melakukan pengamatan secara langsung, penyebaran kuisioner dan wawancara. Dalam penelitian ini analisis AHP digunakan sebagai penentuan konsep pengembangan objek wisata WAM di Kelurahan Gunung Anyar Tambak Surabaya. Penelitian ini menghasilkan arahan kebijakan mengenai konsep pengembangan potensi objek wisata WAM agar dapat dikembangkan. Objek wisata WAM memiliki potensi alam berupa pemandangan yang indah dan alami, berbagai jenis fauna dan flora seperti burung-burung dan hutan mangrove. Arahan kebijakan yang dirumuskan menunjukan bahwa konsep pengembangan potensi wisata WAM agar meningkatkan daya tarik wisata, sehingga dapat meningkatkan penghasilan masyarakat setempat, meningkatkan kualitas hutan mangrove sehingga tetap terjaga, selain berwisata, bisa menjadi tempat pendidikan/penelitian. Dengan dukungan dari pemerintah dan peran serta masyarakat setempat. Karakter Objek Wisata Anyar Mangrove (WAM) termasuk dalam jenis wisata lokal yang memiliki potensi alam yang indah dan alami, pemandangan yang indah, dan terdapat berbagai jenis fauna dan flora. Pemanfaatan lahan pada kawasan objek wisata WAM merupakan kawasan konservasi managrove, tambak ikan, dan perumahan. Jumlah wisatawan yang berkunjung ke objek wisata WAM merupakan wisatawan lokal dengan tujuan rekreasi atau bersantai, tetapi masih dalam jumlah yang sedikit. Sarana dan prasarana wisata serta akses jalan masih dalam kondisi kurang baik. Objek wisata WAM memiliki banyak potensi yang perlu di kembangkan, selain itu melakukan promosi tentang potensi wisaata yang ada untuk menarik daya tarik wisatawan.
\end{abstract}

Kata Kunci : Pengembangan, Potensi, Objek Wisata Anyar Mangrove (WAM).

\section{PENDAHULUAN}

Potensi sumber daya pesisir timur kota Surabaya sangat strategis untuk mengembangkan wisata demi meningkatkan perekonomian dan kesejahteraan masyarakat. Salah satu sumber daya di wilayah pesisir yang sangat strategis untuk dikembangkan sebagai wisata adalah ekosistem mangrove. Hutan mangrove juga menyediakan habitat alami yang unik bagi berbagai macam flora dan fauna laut serta air payau. Hutan mangrove sangat berpotensi untuk dikembangkan sebagai wisata karena memiliki banyak keunikan dan kekhasan tersendiri, salah satunya seperti memiliki bentuk perakarannya yang unik dan khas serta berbagai jenis fauna seperti Monyet, Burung, Ular, Udang, Ikan, Kepiting dan lain-lain. Selain itu, bisa dikembangkan sebagai wisata alam yang berkelanjutan untuk tujuan pendidikan dan konservasi didalamnya sehingga kelestariannya tetap terjaga.Wilayah Surabaya khususnya di
Kecamatan Gunung Anyar merupakan salah satu kawasan yang tumbuh tanaman mangrove. Di kecamatan Gunung Anyar terdapat berbagai macam jenis taman mangrove yang memanjang di sepanjang sungai, selain itu terdapat berbagai macam satwa yang hidup di kawasan tersebut.

Wisata Anyar Mangrove atau disingkat dengan WAM, adalah objek wisata baru di surabaya, tepatnya di kelurahan Gunung Anyar-Rungkut. Area wisata yang berada di sekitar $2 \mathrm{~km}$ ke arah timur kampus UPN, selain menonjolkan hutan mangrove yang alami, juga dilengkapi dengan hewan-hewan yang masih langka, semisal monyet berekor panjang.

\footnotetext{
*) Mahasiswa Perencanaan wilayah dan Kota (PWK)

${ }^{* *}$ ) Dosen Perencanaan Wilayah dan Kota (PWK) Universitas PGRI Adi Buana Surabaya
} 
Selain monyet, kita bisa menikmati berbagai spesies burung sepanjang perjalanan menuju area mangrove. Untuk itu demi meningkatkan kualitas wisata WAM guna meningkatkan kelestarian ekosistem mangrove, lingkungan, ekonomi dan kesejahteraan maka perlu untuk di kembang. Berdasarkan uraian tersebut di atas, maka penelitian dengan judul "Studi Pengembangan Potensi Objek Wisata Anyar Mangrove (WAM) di Kelurahan Gunung Anyar Tambak Surabaya", penting dilakukan guna mengembangan Objek Wisata Anyar Mangrove di kelurahan Gunung Anyar Tambak.

\section{Tujuan Studi}

Dari latar belakang di atas, maka tujuan dari studi ini adalah sebagai berikut :

1. Untuk mengetahui karakteristik Objek Wisata Anyar Mangrove (WAM) di Kelurahan Gunung Anyar Tambak.

2. Untuk mengetahui karakter wisatawan di Objek Wisata Anyar Mangrove (WAM).

3. Untuk mengetahui kondisi sarana dan prasarana penunjang Objek Wisata Anyar Mangrove (WAM).

4. Untuk mengetahui bagaimana konsep pengembangan Objek Wisata Anyar Mangrove (WAM) yang berkelanjutan.

\section{Metode Penelitian}

Pendekatan/jenis penelitian yang digunakan dalam studi pengembangan objek Wisata Anyar Mangrove (WAM) adalah metode penelitian deskriptif kualitatif, dengan melakukan pengamatan secara langsung, penyebaran kuisioner, wawancara, serta dokumen. Metode penelitian deskriptif kualitatif adalah metode penelitian yang menggambarkan temuan variabel dilapangan yang tidak memerlukan skala hipotesis. Jadi, sifatnya hanya menggambarkan temuan dilapangan atau fenomena yang diteliti dengan sistematis, faktual, dan akurat. Analisis kualitatif ini di gunakan untuk menganalisis karakteristik objek wisata, karakter wisatawan, kondisi sarana dan prasarana, dan jenis atraksi wisata. penelitia yang di rancang untuk mempermudah dalam proses melakukan penelitian. Analisis hirarki proses AHP merupakan pendekatan praktis untuk memecahkan masalah dan mengambil keputusan yang kompleks yang meliputi perbandingan alternatif. AHP memungkinkan pengambilan keputusan menyajikan hubungan hirarki antara faktor, atribut, karakteristik atau alternatif dalam lingkungan pengambilan keputusan multi faktor (Badiru, 1995). Oleh sebab itu metode analisis hirarki proses (AHP) digunakan dalam penelitian ini sebagai penentuan dan perumusan konsep terhadap pengembangan objek wisata anyar mangrove. Adapun kerangka penelitian yang digunakan dalam penelitian ini selengkapnya dapat dilihat pada diagram berikut:

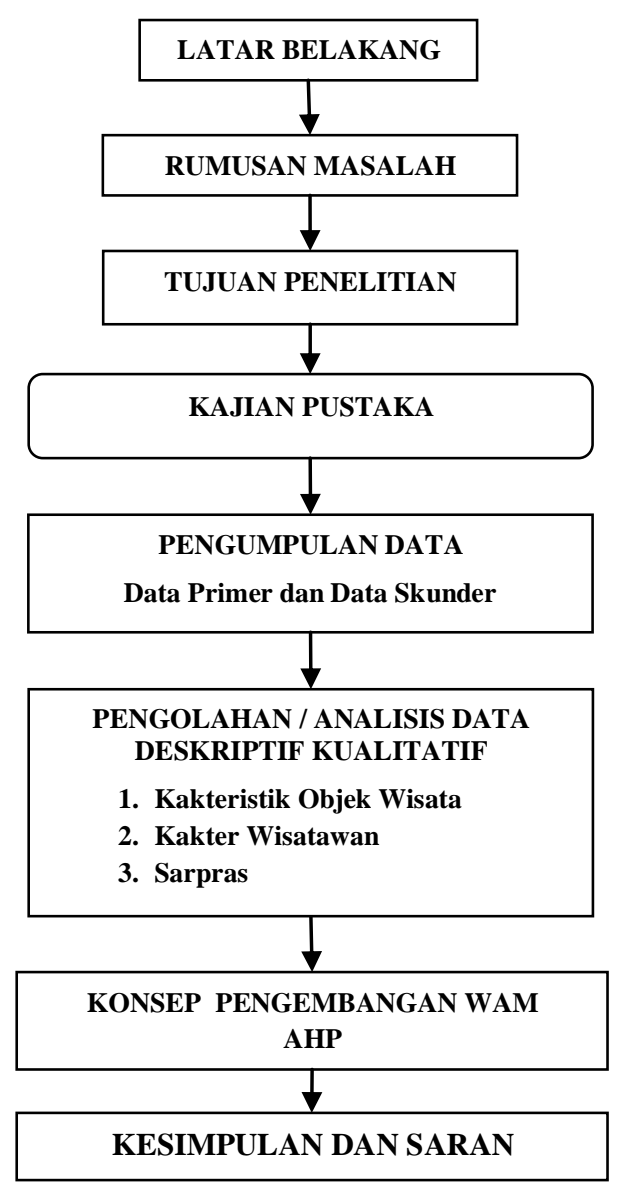

Gambar 1 : Bagan Alur Penelitian 


\section{KAJIAN PUSTAKA}

a. Pariwisata

Menurut Wardiyanto dan Baiquni (2011) Pariwisata adalah kegiatan atau aktivitas yang dilaksanakan untuk sementara waktu dalam rangka menambah wawasan bidang sosial kemasyarakatan, sistem perilaku dari manusia itu sendiri dengan berbagai dorongan kepentingan sesuai dengan budaya yang berbeda-beda yang berhubungan dengan upaya mencari kesenangan, termasuk pengusahaan objek dan dayatarik wisata serta usaha lain yang terkait di bidang tersebut. Sedangkan menurut Marpaung (2002), Pariwisata adalah pemindahan sementara yang dilakukan manusia dengan tujuan keluar dari pekerjaan-pekerjaan rutin, keluar dari tempat kediamannya. MenurutYoeti (1996), Pariwisata adalah suatu perjalanan yang dilakukan untuk sementara waktu, yang diselenggarakan dari suatu tempat ketempat yang lain, dengan maksud bukan berusaha (business) atau mencari nafkah ditempat yang dikunjungi, tetapi semata-mata untuk menikmati perjalanan tersebut guna pertamasyaan dan rekreasi atau untuk memenuhi keinginan yang beranekaragam. Wisata menurut UU RI No. 10 Tahun 2009 Tentang Kepariwisataan adalah kegiatan perjalanan yang dilakukan oleh seseorang atau sekelompok orang dengan mengunjungi tempat tertentu untuk tujuan rekreasi, pengembangan pribadi, mempelajari keunikan daya tarik wisata yang dikunjungi dalam jangka waktu sementara.

b. Objek dan Daya Tarik Wisata

Menurut Yulianda (2006), wisata dapat diklasifikasikan menjadi tiga bagian, antara lain:

- Wisata alam (nature tourism), merupakan aktifitas wisata yang ditujukan pada pemanfaatan sumber daya alam atau daya tarik panoramanya.

- Wisata budaya (cultural tourism), merupakan wisata dengan kekayaan budaya sebagai obyek wisata dengan penekanan pada aspek pendidikan.

- Ecotourism, green tourism atau alternative tourism, merupakan wisata berorientasi pada lingkungan untuk menjembatani kepentingan perlindungan sumber daya alam/lingkungan dan industri kepariwisataan.

MenurutYoeti (1996), objek wisata adalah segala sesuatu (kondisi fisik: iklim, bentang alam, flora dan fauna, dan lainya; hasil ciptaan manusia: benda-benda bersejarah, monument dan rumah adat, dan tata cara hidup masyarakat, upacara tradisional, adat istiadat dan lainnya) yang menjadi daya tarik bagi orang untuk mengunjunginya.

Marpaung (2002) telah mengklasifikasikan daya tarik wisata kedalam 3 (tiga) klasifikasi;

- Daya tarik alam

- Daya tarik budaya

- Daya tarik buatan manusia

\section{c. Sarana dan Prasarana Wisata}

Dalam pengembangan pariwisata, aksesibilitas yang berkenaan dengan sulit atau mudahnya seorang wisatawan mencapai suatu objek wisata. Aksesibilitas perlu diperhatikan mengingat aspek tersebut bisa memberikan pengaruh yang besar bagi para wisatawan. Beberapa hal yang mempengaruhi aksesibilitas suatu tempat adalah kondisi jalan, tarif angkutan, jenis kenderaan, jaringan transportasi, jarak tempuh dan waktu tempuh. Semakin baik aksesibilitas suatu objek, wisatawan yang berkunjung dapat semakin banyak jumlahnya. Kemajuan fasilitas transportasi mendorong kemajuan pariwisata dan sebaliknya ekspansi yang terjadi dalam industri pariwisata dapat menciptakan permintaan akan transportasi yang dapat memenuhi kebutuhan wisatawan. Menurut Yoeti (1996) dalam kepariwisataan terdapat tiga macam transportasi yang dapat digunakan oleh wisatawan yaitu:

- Transportasi Udara

- Transportasi Laut

- Transportasi Darat

d. Wisatawan

Menurut Yoeti (1996) wisatawan adalah seseorang yang meninggal tempat kediamannya untuk sementara waktu dengan alasan apapun juga tanpa memangku jabatan atau pekerjaan di negara yang dikunjunginya. Salah satu unsur yang sangat penting dalam pariwisata adalah wisatawan atau orang yang berkunjung kesuatu tempat untuk bersenangsenang. Berdasarkan jenis-jenis wisatawan, Yoeti (1996) telah membagi wisatawan kedalam beberapa jenis, antara lain:

- Wisatawan asing (Foreign Tourist), orang asing yang melakukan perjalanan wisata, yang datang memasuki suatu negara lain yang bukan negara dimana ia tinggal.

- Domestic Foreign Tourist, orang asing yang berdiam atau bertempat tinggal pada suatu negara, yang melakukan perjalanan wisata di wilayah negara dimana ia tinggal. Domestic Tourist, wisatawan dalam negeri, yaitu seorang warga negara suatu negara yang melakukan perjalanan wisata dalam 
batas wilayah negaranya sendiri tanpa melewati perbatasan negaranya.

- Indigenous Foreign Tourist, warga negara suatu negara tertentu, yang karena tugasnya atau jabatannya berada di luar negeri, pulang kenegara asalnya dan melakukan perjalanan wisata di wilayah negaranya sendiri.

- Transit Tourist, wartawan yang sedang melakukan perjalanan wisata kesuatu negara tertentu, yang terpaksa mampir atau singgah pada suatu pelabuhan/airport/stasiun bukan atas kemauannya sendiri.

- Business Tourist, orang yang melakukan perjalanan untuk tujuan bisnis, bukan wisata tapi perjalanan wisata akan dilakukannya setelah tujuannya yang utama selesai. Jadi, perjalanan wisata merupakan tujuan sekunder, setelah tujuan primer yaitu bisnis selesai dilakukan.

Karakter wisatawan antara lain adalah jumlah wisatawan, umur/usia wisatawan, tingkat pendidikan wisatawan, asal dan jenis wisatawan, tujuan kunjungan, motif kunjungan,

\section{HASIL PENELITIAN}

1. Analisa Karakteristik Objek Wisata WAM

Berdasarkan analisa yang dilakukan, objek wisata anyar mangrove memiliki kondisi alam yang tenang dan alami, udara yang sejuk, pemandangannya yang indah, dan terdapat berbagai jenis satwa yang masih langka. Wisata Anyar Mangrove (WAM) terletak di Kelurahan Gunung Anyar Tambak, Kecamatan Gunung Anyar Kota Surabaya. Wisata anyar mangrove memiliki kodisi topografi yang datar sehingga memberi kesan pada objek wisata terasa nyaman. Selain itu, Objek Wisata Anyar Mangrove (WAM) memiliki kondisi klimatologi yang mencirikan panasnya suhu udara mengakibatkan objek wisata anyar mangrove (WAM) asyik untuk di kunjungi. Karena pada Objek Wisata Anyar Mangrove (WAM) identik dengan ekosistem mangrove yang begitu banyak sehingga membuat suasana menjadi lebih sejuk walaupun panasnya terik matahari. Pola tata guna lahan yang ada di Objek Wisata Anyar Mangrove (WAM) Kelurahan Gunung Anyar Tambak antara lain sebagai tambak ikan, kawasan konservasi hutan mangrove dan kawasan permukiman. Adapun lahan yang di pergunakan sebagai kawasan non-pertanian sebesar 19.20 Ha, pertanian non-sawah sebesar $422.77 \mathrm{Ha}$. Kawasan nonpertanian yang maksud berupa perumahan/permukiman, fasilitas publik, perdagangan dan jasa, sedangkan pertanian frekuensi dan waktu kunjungan, dan tipe kunjungan (Suwantoro, 2004).

\section{e. Mangrove}

Menurut Wijayanti (2009) mangrove adalah suatu komunitas tumbuhan atau suatu individu jenis tumbuhan yang membentuk komunitas tesebut di daerah pasang surut, hutan mangrove atau yang sering disebut hutan bakau merupakan sebagian wilayah ekosisten pantai yang mempunyai karakter unik dan khas terdiri atas lingkungan biotik dan abiotik yang saling berinteraksi di dalam suatu habitat mangrove. Sedangkan ekosistem mangrove menurut Santoso (2000) dalam Zulkifly (2008) adalah suatu sistem di dalam tempat berlangsungnya kehidupan yang mencerminkan hubungan timbal balik antara makhluk hidup dengan lingkungannya dan diantara makhluk hidup itu sendiri. Ruang lingkup konservasi hutan mangrove meliputi usaha perlindungan, pelestarian alam dalam bentuk penyisihan areal sebagai kawasan suaka alam baik untuk perairan laut, pesisir dan hutan mangrove.

non-sawah berupa tambak dan kawasan konservasi hutan mangrove. Akan tetapi kondisi dan keberadaan hutan mangrove semakin berkurang, karena diakibatkan oleh adanya pemanfaatan tambak ikan yang semakin meluas. Atraksi yang ada di Objek Wisata Anyar Mangrove (WAM) Kelurahan Gunung Anyar Tambak beupa atraksi yang masih alami, karena memiliki pemandangan lautan yang indah, dengan suasana yang tenang dan alami.

\section{Analisa Karakter Wisatawan}

Berdasarkan jumlah responden yang diambil oleh peneliti sebanyak 33 responden, maka karakter wisatawan berdasarkan usia yang berkunjung ke wisata anyar mangrove di dapatkan hasil sebanyak 20 responden (60.6\%) dengan usia $15-24$ tahun, sebanyak 9 responden $(27.3 \%)$ dengan usia $25-34$ tahun, dan sebanyak 4 responden (12.1\%) dengan usia 35 - 44 tahun. Analisa karakter wisatawan berdasarkan asal wisataswan sebanyak 23 responden $(69.7 \%)$ berasal dari kota surabaya, dan 10 responden (30.3\%) berasal dari Sidoarjo. Analisa karakter wisatawan berdasarkan tujuan kunjungan wisatawan sebanyak 25 responden (75.8\%) memiliki tujuan berekreasi, dan 8 responden (24.2\%) memiliki tujuan penelitian. Analisa karakter wisatawan berdasarkan waktu kunjungan wisatawan sebanyak 28 responden $(84.8 \%)$ berkunjung pada hari minggu, dan 5 
responden (15.2\%) berkunjung pada hari libur. Analisa karakter wisatawan berdasarkan atraksi wiasata yang di sukaui oleh wisatawan sebanyak 33 responden (100\%) wisatawan menyukai atraksi wisata alam yang memiliki daya tarik wisata yang alami dan menarik pada objek wisata anyar mangrove gunung anyar tambak berupa memiliki pemandangan laut dan hutan mangrove yang indah, udara yang segar dan berbagai jenis fauna dan flora.

\section{Analisa Kondisi Sarana dan Prasarana Wisata}

Dari jumlah responden yang diambil oleh peneliti sebanyak 33 responden, maka kondisi dermaga wisata WAM di kelurahan Gunung Anyar Tambak di dapatkan hasil sebanyak 29 responden $(87.9 \%)$ memilih dalam kondisi baik, dan 4 responden (12.1\%) memilih dalam kondisi sedang. Analisa kondisi perahu/angkutan wisata Anyar Mangrove di kelurahan Gunung Anyar Tambak di dapatkan hasil sebanyak 3 responden $(9.1 \%)$ memilih dalam kondisi baik, dan 30 responden (90.9\%) memilih dalam kondisi sedang. Analisa kondisi tempat peristirahatan untuk wisatawan yang berkunjung ke wisata Anyar Mangrove di kelurahan Gunung Anyar Tambak di dapatkan hasil sebanyak 3 responden (10.0\%) memilih dalam kondisi baik, 20 responden (66.7\%) memilih dalam kondisi sedang, dan 10 responden $(30.30 \%)$ memilih dalam kondisi buruk. Analisa kondisi toilet/WC yang ada di objek wisata anyar mangrove kelurahan gunung anyar tambak di dapatkan hasil sebanyak 33 responden (100\%) memilih dalam kondisi buruk. Analisa kondisi tempat sampah yang ada di objek wisata Anyar Mangrove kelurahan Gunung Anyar Tambak di dapatkan hasil sebanyak 8 responden (24.2\%) memilih dalam kondisi baik, 18 responden $(54.5 \%)$ memilih kondisi sedang, dan 7 responden (21.2\%) memilih dalam kondisi buruk. Analisa kondisi jalan akses ke objek wisata Anyar Mangrove kelurahan Gunung Anyar Tambak di dapatkan hasil sebanyak 4 responden (12.1\%) memilih dalam kondisi baik, 19 responden $(57.6 \%)$ memilih kondisi sedang, dan 10 responden (30.3\%) memilih dalam kondisi buruk. Analisa ketersediaan tempat parkir pada objek wisata Anyar Mangrove kelurahan Gunung Anyar Tambak di dapatkan hasil sebanyak 33 responden $(100 \%)$ memilih dalam tidak ada. Analisa ketersidiaan kantor pengelola objek wisata Anyar Mangrove kelurahan Gunung Anyar Tambak di dapatkan hasil sebanyak 33 responden (100\%) memilih dalam kondisi tidak ada.
Berdasarkan potensi dan permasalahan diatas maka dilakukan perumusan konsep pengembangan objek wisata WAM menggunakan analisa AHP. Analisa prioritas AHP menggunakan program komputer (Expert Choice). Oleh sebab itu dari hasil kuisioner yang dijawab oleh responden diperolehhasil Dari hasil prioritas konsep pengembangan wisata, menghasilkan Konsep 2 sebagai prioritas pertama dengan bobot sebesar 0,49 dan kriteria yang paling berpengaruh adalah kriteria Karakteristik objek wisata dengan nilai sebesar 0,62, selain itu konsep 3 sebagai prioritas ke dua dengan bobot sebesar $0,30 \%$, konsep 4 sebagai priorotas ke tiga dengan bobot sebesar 0,12 \%, dan konsep 1 sebagai prioritaske empat dengan bobot sebesar 0,8 $\%$. Grafik penilaian prioritas dapat dilihat pada Gambar 5.16.dengan cara yang sama dilakukan analisis terhadap hasil kuisioner responden yang lain. Lebih jelasnya dapat dilihat pada Grafik berikut :
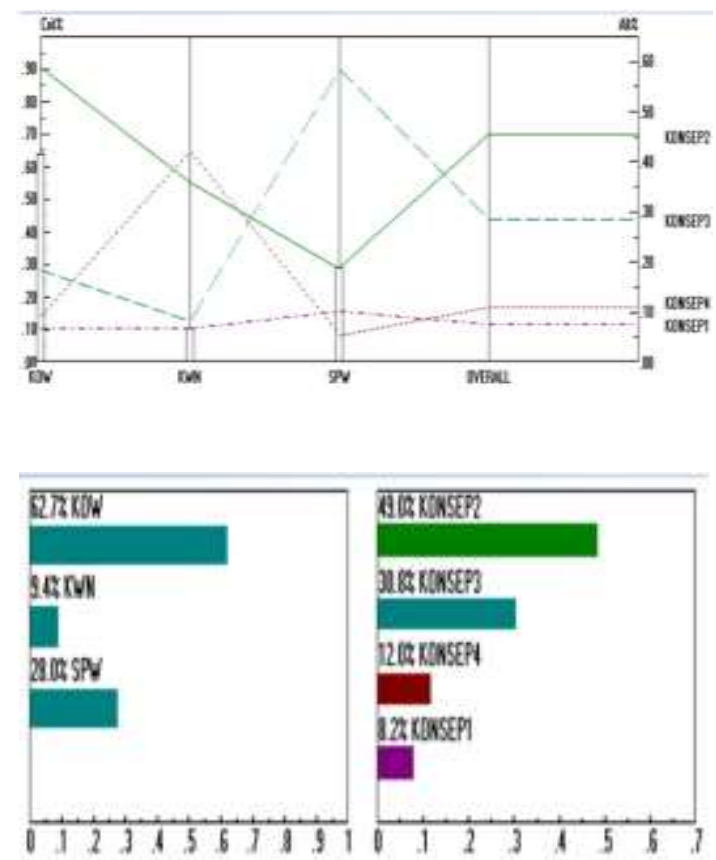

Gambar 5 : Grafik Nilai Prioritas Perumusan Konsep Pengembangan

\begin{tabular}{|c|c|c|c|c|c|c|}
\hline & $\mathrm{R} 1$ & R2 & R3 & R4 & $\begin{array}{l}\text { Jumla } \\
\mathrm{h}\end{array}$ & $\begin{array}{l}\text { Priorit } \\
\text { as }\end{array}$ \\
\hline $\begin{array}{l}\mathrm{K} \\
1\end{array}$ & 0,9 & 0,8 & 0,8 & 0,7 & 0,32 & IV \\
\hline $\begin{array}{l}\mathrm{K} \\
2\end{array}$ & $\begin{array}{l}0,4 \\
9\end{array}$ & $\begin{array}{l}0,4 \\
6\end{array}$ & $\begin{array}{l}0,3 \\
8\end{array}$ & $\begin{array}{l}0,3 \\
2\end{array}$ & 2,26 & 1 \\
\hline $\begin{array}{l}\mathrm{K} \\
3\end{array}$ & $\begin{array}{l}0,3 \\
9\end{array}$ & $\begin{array}{l}0,3 \\
0\end{array}$ & $\begin{array}{l}0.3 \\
0\end{array}$ & $\begin{array}{l}0,2 \\
0\end{array}$ & 1,19 & II \\
\hline $\begin{array}{l}\mathrm{K} \\
4\end{array}$ & $\begin{array}{l}0,3 \\
3\end{array}$ & $\begin{array}{l}0,1 \\
9\end{array}$ & $\begin{array}{l}0,1 \\
5\end{array}$ & $\begin{array}{l}0,1 \\
2\end{array}$ & 0,79 & III \\
\hline
\end{tabular}

Tabel 5 : Hasil Perhitungan Prioritas Konsep Pengembangan 
Prioritas 1: Mengembangkan potensi wisata dengan meningkatkan penanaman mangrove dan melestarikan flora dan fauna untuk dijadikan sebagai daya tarik wisata alam.

Prioritas 2: Peningkatan dan pengembangan kapasitas sarana dan prasarana wisata serta akses jalan ke objek wisata sesuai dengan pemanfaatan ruang.

Prioritas 3: Melakukan promosi ke publik melalui media masa, elektronik, maupun media cetak.

Prioritas 4: Untuk keberlanjutan pengembangan dan pelestarian objek wisata WAM, maka diserahkan kepada pemerintah kota Surabaya dengan melibatkan peran serta masyarakat.

\section{PEMBAHASAN}

Berdasarkan analisa deskriptif kualitatif maka dapat diketahui bahwa karakteristik objek wisata WAM memiliki banyak potensi wisata yang perlu untuk dikembangkan. Potensi yang ada berupa memiliki kondisi alam yang tenang dan alami, udara yang sejuk, pemandangan yang indah dan terdapat berbagai jenis fauna dan flora. Dengan potensi yang ada tersebut bisa dikembangkan untuk meningkatkan daya tarik para wisatawan untuk berkunjung. Pemanfaatan lahan pada kawasan objek wisata WAM sebagai kawasan perumahan, tambak ikan dan kawasn konservasi hutan mangrove.

Wisatawan yang mengunjungi objek wisata WAM memiliki berbagai karakter kunjungan. Contohnya seperti karakter wisatawan berdasarkan usia yang berkunjung ke Wisata Anyar Mangrove di dominasi oleh sekelompok umur antara 15 - 24 tahun atau sebanyak 60.6 $\%$. Dimana pada usia $15-24$ tahun dapat di ketahui karakter wisatawan yang berkunjung ke objek wisata Anyar Mangrove mempunyai karakter wisata, yaitu :

- Dengan usia yang muda dapat dikatan sebagai remaja yang lebih menyukai untuk berekreasi.

- Mempunyai motivasi dan kepentingan untuk mengisi waktu senggang untuk bersantai.

Sebagian besar wisatawan yang berkunjung ke objek wisata masih wisatawan lokal yang berasal dari kota Surabaya dan sekitarnya. Tujuan kunjungan wisatawan hanya untuk berekreasi, selain itu terdapat pula kunjungan dengan tujuan penelitian. Waktu kunjungan wisatawan biasa dilakukan pada hari minggu dan hari-hari libur. Wisatawan memilih berkunjung ke objek wisata WAM karena memiliki daya tarik tersendiri, berupa pemandangan yang indah, udara yang sejuk, dan lain sebagainya. Wisata WAM memiliki kondisi sarana dan prasarana yang masih kurang baik. Hal ini diakibatkan karena kurangannya pengembangan dan peningkatan mutuh kualitas sarana dan prasarana yang ada pada objek wisata WAM. Sarana dan prasarana sangat berperan aktif dalam perkembangan pariwisata itu sendiri. Sedangkan dari analisa AHP dapat merumuskan beberapa konsep terhadap pengembangan objek wisata WAM. Perumusan konsep pengembangan objek wisata WAM perlu dilakukan agar perencanaan yang akan dikembangan atau dilaksanakan bisa berjalan dengan baik sebagaimana sesuai dengan konsep yang telah di buat.

\section{Simpulan dan Saran}

1. Simpulan

Pariwisata merupakan salah satu sumber daya alam yang memiliki daya tarik tersendiri yang dapat menarik wisatawan untuk berkunjung. Kawsan konservasi merupakan salah satu kawasan hutan yang di lindungi karena memiliki berbagai manfaat dan potensi, salah satunya adalah potensi wisata. Objek wisata Anyar Mangrove merupakan salah satu objek wisata alam yang memiliki berbagai macam potensi. Wisata anyar mangrove mulai dikembangkan pada tahun 2010, dan pada tahun tersebut wisata WAM mulai dikelola. Wisata Anyar Mangrove juga sangat mempengaruhi kondisi tata guna lahan pada sekitar kawasan objek wisata. Pengembangan wisata Anyar Mangrove sangat penting di kelolah dengan baik, agar tidak terjadi kesalahan dalam mengelolahnya. Karena kawasan Objek Wisata Anyar Mangrove merupakan kawasan konservasi, jadi harus melakukan pengembangan secara benar. Baik dari pengembangan atraksi wisata atau sarana dan prasarana harus benar-benar memperhatikan kebijakan pemanfaatan ruang. Berdasarkan hasil penelitian yang dilakukan berkaitan dengan Pengembangan Potensi Objek Wisata Anyar Mangrove (WAM), dapat disimpulakan bahwa : 
a) Wisata Anyar Mangrove berdasarkan analisa karakteristik objek wisata, wisata WAM termasuk dalam jenis wisata lokal dan wisatawan yang datang pun merupakan wisatawan lokal. Hal ini disebabkan karena masih kurang pengembangan terhadap potensipotensinya yang ada. Sedangkan potensi wisata WAM cukup banyak dan bagus, berupa memiliki konsidisi alam yang indah dan alami, berbagai jenis fauna dan flora yang di jadikan sebagaai daya tarik wisata. Kondisi pemanfaatan lahan di kawasan objek wisata WAM masih kurang baik. Pemanfaatan lahan yang lebih dominan adalah pengembangan perumahan, tambak ikan, dan kawasan konsevasi hutan mangrove. Kondisi hutan mangrovepun sudah semakin berkurang di akibatkan pengembangan tambakan ikan dan pengembangan perumahan. Apabilah hal ini tidak di kelolah dengan baik khususnya pemberdayaan hutan mangrove, maka wisata WAM pun tidak bisa di kembangkan.

b) Wisatawan yang berkunjung ke objek wisata WAM masih dalam jumlah yang sedikit, dan wisatawan yang datang berasal dari dalam lokal sendiri dengan tujuan menikmati pemandangan alam wisata yang memiliki suasana yang indah dan tenang. Wisata dengan alam yang asri disekitarnya dapat memberikan kesejukan, nyaman bagi siapapun. Objek wisata WAM memiliki keindahan alam, kesejukan iklim, sesuai lingkungan merupakan modal untuk berkembangya kegiatantan wisata.

c) Berdasarkan analisa sarana dan prasana pada objek wisata WAM masih belum baik, terdapat beberapa fasilitas wisata yang masih kurang dan ada juga yang belum di kembangkan. Salah satu contoh seperti fasilitas kantor pengelolah wisata. Wisata WAM perlu dilakukan pengembangan agar dapat menarik wisatawan untuk datang berkunjung. Karena dengan demikian dapat memberi berbagai keuntungan. Jalan akses menuju ke objek wisata WAM masih terdapat beberapa jalan yang belum baik karena masih rusak. Aspek trasportasi sangat penting untuk di kembangkan karena denga adanya sarana dan prasana berupa akses jalan maka kegiatan kepariwisataan akan lebih lancar. d) Wisata WAM merupakan wisata yang baru dan harus mendapat perhatian yang khusus untuk dikembangkan, guna untuk menjaga kelestarian fauna dan flora. Berdasarkan analisa yang di lakukan menggunakan analisis AHP dapat dirumuskan beberapa konsep dalam mengembangkan objek wisata WAM. Perlu menentukan konsep agar pembangunan bisa dilaksanakan sesuai rencana dan dapat di manfaatkan dengan baik. Adapun hasil analisis alternative konsep pengembangan objek wisata WAM menggunakan Analisa AHP didapat 4 (empat) prioritas konsep pengembangan Wisata WAM dengan urutan sebagai berikut :

Konsep 1: Mengembangkan potensi wisata dengan meningkatkan penanaman mangrove dan melestarikan flora dan fauna untuk dijadikan sebagai daya tarik wisata alam.

Konsep 2: Peningkatan dan pengembangan kapasitas sarana dan prasarana wisata serta akses jalan ke objek wisata sesuai denga pemanfaatan ruang kawasan.

Konsep 3: Melakukan promosi ke publik melalui media masa, elektronik, maupun media cetak.

Konsep 4: Untuk keberlanjutan pengembangan dan pelestarian objek wisata WAM, maka diserahkan kepada pemerintah kota Surabaya dengan melibatkan peran serta masyarakat.

\section{Saran}

Hasil analisa yang diperoleh dari berbagai macam analisa yang ditujukan pada studi pengembangan objek wisata anyar mangrove (WAM) di kelurahan Gunung Anyar Tambak kota Surabaya. Pengembangan objek wisata khusunya wisata alam harus benar-benar di kembangkan dengan baik, agar kualitas dan kuantitas alamiahnya tetap terjaga dan berkelanjutan. Dan untuk mewujudkan pengembangan objek wisata WAM harus di perlukan beberapa studi terhadap :

a) Harus di lakukan dan memperhatikan penataan kawasan wisata anyar mangrove terutama pada pola penggunaan lahan yang akan dikembangkan sarana dan prasarana wisata. Sarana dan parasarana yang di kembangkan harus tetap memperhatikan kibijakan pemanfaatan ruangnya. Dalam 
mengembangkan kawasan wisata WAM

harus tetap menjaga kualitas lingkungan.

b) Perlu melakukan penanaman dan pelestarian hutan mabgrove agar kualitas wisata tetap terjaga dan berkelanjutan. Untuk membangun fasilitas harus didasarkan pada keinginan semata tanpa melalui kajian secara matang, karena dikawatirkan makna alami dari sutu kawasan wisata WAM akan terganggu atau hilang oleh karena itu pengembangan wisata WAM harus tetap menjaga keindahan dan kenyamanannya.

c) Perlu meningkatkan pengembangan dan pelestarian sarana prasarana wisata WAM untuk meningkatkan kualitas wisata dan daya tarik wisatawan. Selain itu melakukan promosi atau mempublikasikan objek Wisata Anyar Mangrove (WAM) agar wisatawan local maupun wisatawan manca negara mengetahui bahwa Wisata Anyar Mangrove memiliki potensi wisata alam. 


\section{DAFTAR PUSATAKA}

Marpaung, H. 2002. Pengetahuan Kepariwisataan. Alfabeta, Bandung.

Yoeti, H. Oka A. 1996. Pengantar Pariwisata. Angkasa, Bandung.

Suwantoro, G. 2004. Dasar-Dasar Pariwisata. Andi, Yogyakarta.

WardiyantodanBaiquni, M. 2011. Perencanaan Dan Pengembangan

Pariwisata. LubukAgung, Bandung.

Sangadji, E.M, danSopiah, 2010. MetodePenelitian, Pendekatan Praktisi

Dalam Penelitian. Andi, Yogyakarta.

Yulianda, F, 2006. Ekowisata Bahari sebagai Alternatif Pemanfatan

Sumber Daya Pesisir Berbasis Konservasi. Makalah Seminar Sehari

Pengelolaan Sumber Daya Pesisir dan Laut, Institut Pertanian Bogor.

Warpani Suwardjoko, P. 2007. Pariwisata Dalam Tata Ruang Wilayah. ITB

Bogor. Soekadijo, 2000. Anatomi Pariwisata Gramedia Pustaka

Utama. Jakarta Indonesia.

Romimohtarto, K dan Juwana, S. 2001. Biologi Laut, IImu Pengetahuan

Tentang Biologi Laut. Djambatan, Jakarta.

Zulkifly, 2008. Kajian Tingkat Keberhasilan Rehabilitas Vegetasi Mangrove

Ditinjau Dari Bioekologi Di Pantai Tokke-Tokke Kecamatan

Pitungpanua Kabupaten Wajo. Universitas Hasanudin Makassar,

Makassar.

Amiani, 2008.Pengembangan Ekowisata yang berbasis Masyarakat Menuju

Pariwisata Berkelanjutan Di Kelurahan Serangan, Bali. Jurnal

Kepariwisataan Indonesia.

Begen, D.G. 2001. Pedoman Teknis Pengenalan dan Pengelolaan Ekosistem

Mangrove. Pusat Kajian Sumberdaya Pesisir dan Lautan, Institut

Pertanian Bogor. Bogor, Indonesia.

Wijayanti, Tri, 2009. Konservasi Hutan Mangrove Sebagai Wisata Pendidikan,

Surabaya. Jurnal Teknik Lingkungan UPN Veteran JawaTimur.

Adiwijaya, Hendra, 2009. Kondisi Mangrove Pantai Timur Surabaya dan

Dampaknya Terhadap Lingkungan Hidup, Surabaya. Jurnal Teknik

Lingkungan UPN Veteran Jawa Timur.

Shanty, 2011.Analisis Persepsi Wisatawan Yang Berkunjung Ke Pulau Samosir.

Undang-Undang Republik Indonesia, Nomor 10 Tahun 2009. Tentang

Kepariwisataan. Fokusindo Mandiri, Bandung.

Peraturan Mentri Kebudayaan Dan Pariwisata, Nomor:

KM.67/UM.001/MKP/2004. Pedoman Umum Pengembangan

Pariwisata Di Pulau-Pulau Kecil, Jakarta.

Peraturan Daerah Kota Surabaya, Nomor 3 tahun 2007. Tentang Rencana Tata

Ruang Wilayah Kota Surabaya. Surabaya

Peraturan Walikota Surabaya, Nomor 65 Tahun 2011, Tentang Prosedur

Pengawasan dan Pengendalian Kawasan Mangrove di Wilayah Kota

Surabaya. Kota Surabaya. 